\title{
Developmental Education for University Students: Ways and Methods of its Organization
}

\section{Educación del desarrollo para estudiantes universitarios: formas y métodos de su organización}

\author{
Irina V. Samarokova \\ Nosov Magnitogorsk State Technical University, Magnitogorsk, Russia \\ ORCID: https://orcid.org/0000-0002-3419-3803 \\ Natalia S. Solovyeva \\ Moscow University of Finance and Law MFUA, Moscow, Russia \\ ORCID: https://orcid.org/0000-0002-0105-1091 \\ Natalia V. Kozhushkova \\ Nosov Magnitogorsk State Technical University, Magnitogorsk, Russia \\ ORCID: https://orcid.org/0000-0003-2544-5287 \\ Yevgenii V. Korobeynikov \\ Nosov Magnitogorsk State Technical University, Magnitogorsk, Russia \\ ORCID: https://orcid.org/0000-0003-2105-1991

\section{Olesya A. Golubeva} \\ Nosov Magnitogorsk State Technical University, Magnitogorsk, Russia \\ ORCID: https://orcid.org/0000-0003-3285-1010

\section{Oksana P. Chernykh} \\ Moscow University of Finance and Law MFUA, Moscow, Russia \\ ORCID: https://orcid.org/0000-0001-8823-5012
}

Received 0-12-20 Revised 01-25-20 Accepted 04-13-20 On line 06-29-20

*Correspondence

Email: samarokovai@mail.ru
Cite as:

Samarokova, I.V., Solovyeva, N.S., Kozhushkova, N.V., Korobeynikov, Y.V., Golubeva, O.A., \& Chernykh, O.P. (2020). Developmental Education for University Students: Ways and Methods of its Organization. Propósitos y Representaciones, 8 (SPE2), e600. Doi: http://dx.doi.org/10.20511/pyr2020.v8nSPE2.5600 


\section{Summary}

This article is devoted to the organization of developmental education of students of higher educational institutions. Based on works by I.A. Zimniaia, T.I. Iliin, V.V. Kraevskii, G.M. Kodzhaspirova, I.Ia. Lerner, I.F. Kharlamov and other researchers, the authors clarified the concept of "developmental education of university students", analyzed its components, systematized domestic and foreign experience in organizing developmental education in a higher educational institution. The article also presents the author's set of pedagogical conditions, which contributes to the organization of developmental education for university students. This set includes the following components: correction of students' value orientations in the educational process of the university; the development of cognitive activity of students and the construction of the educational process at the university, subject to the requirements of a person-centered approach.

Keywords: Developmental Education; University Students; Person-Centered Approach; Cognitive Activity of Students; Value Orientations of University Students.

\section{Resumen}

Este artículo está dedicado a la organización del desarrollo educativo de estudiantes de instituciones de educación superior. Basado en trabajos de I.A. Zimniaia, T.I. Iliin, V.V. Kraevskii, G.M. Kodzhaspirova, I.Ia. Lerner, I.F. Kharlamov y otros investigadores, los autores aclararon el concepto de "educación para el desarrollo de los estudiantes universitarios", analizaron sus componentes, sistematizaron la experiencia nacional y extranjera en la organización de la educación para el desarrollo en una institución de educación superior. El artículo también presenta el conjunto de condiciones pedagógicas del autor, que contribuye a la organización de la educación para el desarrollo de los estudiantes universitarios. Este conjunto incluye los siguientes componentes: corrección de las orientaciones de valor de los estudiantes en el proceso educativo de la universidad; el desarrollo de la actividad cognitiva de los estudiantes y la construcción del proceso educativo en la universidad, sujeto a los requisitos de un enfoque centrado en la persona.

Palabra clave: Educación para el desarrollo; Estudiantes universitarios; Enfoque centrado en la persona; Actividad cognitiva de los estudiantes; Orientaciones de valor de los estudiantes universitarios.

\section{Introduction}

The organization of developmental education is one of the most pressing problems of modern pedagogical science and practice. Learning activities of students are the source of the diverse development of their personality, affecting not only the system of value orientations, but also their attitude to society, work, people, and themselves. Under current transition to multi-level, varied education, in connection with the profiling of educational programs and the strengthening of the individualization of their choice, the educational opportunities for learning increase. Therefore, the developmental education of university students is an important stage in continuing education. It forms a focus on continuing education and self-education, the need for continuous cognitive activity, whose lack makes professional education and the achievement of professional mastery impossible.

Developmental education is a comprehensive research-based framework that empowers underprepared learners to achieve intellectual, social and emotional growth. Developmental education includes, but is not limited to, instruction, coursework, tutoring, personal counseling, career counseling and academic advisement. 
Following a major statewide developmental education reform in Florida, we explored institutional transformation among Florida College System institutions. We used statewide survey data to examine lead administrators' perceptions of challenges encountered during the planning process, ways in which colleges engaged in sensemaking (i.e., social processes for developing shared understanding) and organizational learning, and perceptions of the institutional transformation processes and outcomes following the reform. We found that institutions engaged in numerous types of sensemaking and organizational learning practices to promote change. Yet, despite different approaches taken to institutional transformation, almost all respondents reported that the change process was highly collaborative and involved a broad range of stakeholders.

Community colleges across the nation face increasingly complex internal and external environments, resulting in an increased emphasis on the need for change (Bess and Dee 2012). One area of focus for change is developmental education, given that $68 \%$ of students attending two-year institutions must take developmental (or remedial) courses and that only $28 \%$ of these students graduate within eight years (Community College Research Center 2014). Studies have shown that developmental education may have negative impacts on students including delaying time to gateway course completion (Scott-Clayton and Rodriguez 2015) and reducing credit accumulation (Martorell and McFarlin Jr 2011). In a meta-analysis of developmental education studies using quasi-experimental methods, Valentine et al. (2017) found that students assigned to developmental education who were just below college-ready performed significantly worse on the likelihood of degree completion, credit accumulation, and passing college-level courses relative to similar students who were not assigned to developmental education. Additionally, developmental education can impact students negatively through increased costs and debt related to courses that do not provide college credit. Annually up to $\$ 7$ billion is spent on developmental education expenditures nationwide by students and institutions (Scott-Clayton et al. 2014). In Florida developmental education costs were estimated at \$154 million annually, with students paying \$73 million through tuition (Underhill 2013).

Due to the high cost and lack of effectiveness associated with traditional developmental education programs (e.g. Scott-Clayton et al. 2014; Valentine et al. 2017), many states and college systems have responded by implementing developmental education policies intended (a) to improve assessment and placement into college courses, (b) to promote innovative instructional methods in developmental education courses that accelerate students into credit-bearing courses, or (c) to increase accountability requirements around student success (Whinnery and Pompelia 2019). For example, Minnesota, Oregon, and Washington have encouraged colleges to consider multiple measures for placement since placement tests have been shown to misplace students into developmental education courses (Ngo and Melguizo 2015; Scott-Clayton et al. 2014). California, Tennessee, and Texas have implemented new methods of instruction for developmental education such as corequisite courses where underprepared students enroll directly in introductory college-level (gateway) math and English courses and receive developmental education support at the same time. Additionally, over half of community colleges surveyed on developmental education practices indicated that they have implemented reform initiatives such as using multiple measures for course placement or shortening developmental education course sequences (Rutschow and Mayer 2018).

The reform measures in these states are largely representative of traditional state policy reform in higher education, which most commonly occurs as incremental changes over time instead of rapid and large-scale reforms (Mintrom and Norman 2013). In Florida, however, the state legislature took a more drastic approach by passing broad legislation that required all 28 Florida College System (FCS) institutions (the former community colleges) to make changes beginning in Fall 2014 to many aspects of traditional developmental education placement and instructional strategies all at one time. Prior to this legislative action, students in Florida who did 
not meet placement test score minimums were required to take traditional developmental education courses in mathematics, reading, or writing. For the 2013 cohort enrollment rates in developmental courses were $23 \%$ in reading, $19 \%$ in writing, and $44 \%$ in math (Hu et al. 2019). In 2013 the Florida legislature passed Senate Bill (SB) 1720: a statewide reform of developmental education with full implementation to begin in fall 2014. The first change arising from the reform was that the majority of students became exempt from placement testing and developmental education courses. Exempt students include those who entered a Florida public high school in 2003/04 or later as ninth graders and graduated with a standard high school diploma, as well as active duty military personnel. A survey of student enrollment decisions following the reform indicated that many students did elect to opt out developmental education, even if they were advised to take such courses (Park et al. 2016). However, some students who felt that they were academically underprepared continued to enroll in developmental education, particularly in math. The second change was that FCS institutions were now required to offer the remaining developmental education courses using a specific set of instructional strategies, which were to include compressed, co-requisite, contextualized, or modularized formats. Contextualized courses incorporate content in the course in an applied manner depending on the student's major course pathway, or meta-major. The third change was that the FCS institutions were required to develop a plan to offer enhanced advising and academic support services to improve student success. Administrators reported using a variety of new practices to help students to be successful under the reform, including the use of advising tools such as early warning systems, changes to the student orientation process, and greater availability of advising resources (Woods et al. 2017). All 28 FCS institutions were affected by SB 1720, and the scale of coordination was immense. However, institutions had considerable autonomy in terms of how the changes were implemented, so there was also significant decentralized decision-making at the institutional level.

The Florida reform required significant changes to every day practice in developmental education placement and delivery. Such changes often require modifications to structural processes throughout the organization that challenge organizational ideologies and assumptions to create lasting change-a process known as institutional transformation (Eckel and Kezar 2003). This study contributes to the literature by providing insight into whether and how institutional transformation occurred within the FCS institutions during this large-scale developmental education reform, which required all public colleges to make several substantial changes simultaneously and quickly. We explored the changes made under the reform through the conceptual lenses of sensemaking and organizational learning. Sensemaking refers to the "social process that involves seeking information from others, collectively assigning meaning to the information, and then taking actions based on shared understandings" (Bess and Dee 2012, p. 155). This is relevant to our study since the reform required organizational members to rethink how to prepare students for success in college-level courses and then to construct a collective understanding of how they would develop innovative solutions. The concept of organizational learning refers to the process through which "the knowledge generated by individuals and groups becomes embedded within the structures, strategies, routines, and culture of the entire organization" (Bess and Dee 2012, p. 666). In our context, college administrators and staff had to create and use new knowledge about best practices in order to help students to be successful under the reform, and then share that knowledge throughout the organization.

When students arrive to enroll in community college, almost all are asked to take a skills assessment in math, reading, and writing. Based on these assessments, students are either categorized as "college-ready" and can enroll in college-level classes in the relevant subjects, or they are considered "developmental" or "remedial" students and are referred to academic services designed to raise their skills up to college standards. Many students are referred to multiple levels of remediation - up to five levels in some cases. This means that such students would have to successfully navigate five semesters of precollege instruction before being prepared for their first college-level course. While a variety of other remedial services are offered, the large majority consists of these semester-long developmental classes in the subjects to which students have been referred. About 60 percent of incoming students are referred to at least one developmental 
course. 1 This is often surprising to them since the large majority of community college entrants are high school graduates. And for many, remediation is not just a course, but rather, for those referred to multiple levels, a whole curriculum. Addressing the needs of developmental students is perhaps the most difficult and most important problem facing community colleges. Developmental students face tremendous barriers. Less than one quarter of community college students who enroll in developmental education complete a degree or certificate within eight years of enrollment in college. In comparison, almost 40 percent of community college students who do not enroll in any developmental education course complete a degree or certificate in the same time period. 2 It will be very difficult to meet the Obama administration's goal of increasing the number of community college graduates by 5 million by 2020 without making significant progress on improving outcomes for students who arrive at community colleges with weak academic skills. In this Brief we first report on evidence about the effectiveness (or, unfortunately, in too many cases, the ineffectiveness) of remediation and then provide information about the progression of students through the developmental sequence. We discuss problems associated with the crucial assessments and make a brief statement about costs. We then describe three initiatives designed to improve the performance of remedial services. Effectiveness Do the services provided to students through developmental education programs work to improve student outcomes? Given the size and importance of the developmental function, there are surprisingly few rigorous evaluations, and outcomes from those are not encouraging. Two rigorous studies, one in Florida and one in Texas, found that students who participated in remediation did no better on several outcome measures than similar students who enrolled directly in college-level courses. 3 On the other hand, a study in Ohio, using a more restricted sample, found positive effects for math remediation but none for 47 reading. 4 But the results of these studies are most reliable for referred students whose assessment scores put them close to the remediation cutoff points-that is, these were among the stronger of the students who were referred to developmental education. We know very little about the effectiveness of developmental education for students who score well below the cutoff score, although a study of a program for students in adult basic skills classes in Washington State-the IBEST program-does show promising early outcomes. This will be discussed in more detail below.

We begin by examining the extent to which different types of resistance were encountered among different groups of stakeholders and identifying the common obstacles that arose during the initial planning process. Next, we examine the processes that FCS institutions engaged in to promote sensemaking and organizational learning during the implementation of the developmental education reform. Finally, we explore whether institutional transformation was evident in both attitudinal and structural changes and how this influenced institutional leaders' perceptions of the reform outcomes. We conclude with implications for understanding how institutional transformation occurs following a large-scale reform, which may inform practices in other states engaged in similar initiatives.

\section{Relevance of the problem}

The relevance of the problem of organizing developmental education of university students is determined by a number of contradictions:

- First, educational tasks are often perceived by university teachers as an additional burden that distracts them from teaching specific subjects.

- Secondly, there is an erroneous opinion that the processes of education and upbringing are implemented in parallel, while in a holistic pedagogical process they appear together and simultaneously.

- Thirdly, there is a misunderstanding of the education process as a complex of special events that should be carried out by someone other than the teacher and separately from the educational process of the university. 
Education promotes a gradual introduction of students to the panhuman and national culture and science, to the formation of their own personality as a subject of life. Awareness of the social value of education has a beneficial effect on the activity of the individual and its motivation.

\section{Study of the problem}

Historical and pedagogical analysis of various sources suggests that the problem of the ratio of education and training has long worried pedagogical thought. Even Plato in his "Laws" argued that the most important thing in training is proper education. In the following centuries, many attempts were made to define upbringing and education, to separate these processes and analyze their relationship.

Russian pedagogy of the second half of the XIX - early XX centuries considered developmental education as the main means of educating the spiritual and moral personality (K.D. Ushinskii, V.P. Vakhterov, P.F. Kapterev, and others).

The provision on the indissolubility of upbringing and training was emphasized in the works by Russian scientists and educators in the second half of the XX century (Iu.K. Babanskii, T.I. Iliina, I.F. Kharlamov, and others). I.Ia. Lerner, V.V. Kraevskii, V.A. Petrovskii, B.M. Bim$\mathrm{Bad}$ and others defined upbringing and education as the subsystems of a single process education.

In our study, we rely on the ideas of I.Ia. Lerner, who defined education and upbringing as a single process, involving the assimilation by students of knowledge, skills, experience of creative activity, and emotional upbringing. Moreover, if the first three elements determine the level of intellectual development of a person, then the set of these components makes up the content of the spiritual development of the personality as a whole.

The authors of the article note that modern foreign and domestic researchers of the pedagogical heritage of I.F. Herbart seek to return the idea of developmental education to its true meaning, which does not imply reducing education to learning, but lies in the mechanism of their interaction in the holistic process of personality formation. The noted circumstance determined the choice of the topic of the article.

There are two types of changes that occur within organizations. First order (or incremental) changes are minor improvements, such as those that occur in response to fluctuations in institutional funding (e.g. Eckel et al. 2001; Keller 1983). These types of changes tend to occur more frequently and are easier to accomplish. Second order changes, which are also referred to as transformational changes, involve a more comprehensive set of changes to operational procedures, underlying values, and the culture of the organization (e.g. Gioia et al. 1996; Schein 1992). This type of change is more challenging because postsecondary institutions tend to have long-standing practices and members are not used to making significant changes. It also requires institutions to make larger collective changes instead of only changes among individuals, which is particularly difficult in higher education settings with its decentralized organizational structures and tradition of faculty governance. Since true institutional transformation occurs relatively infrequently in higher education, there are few studies that examine how this process occurs (Kezar 2018).

Social cognition theories of change are used to understand how ongoing learning occurs during the change process (Kezar 2018). This framework can inform our understanding of why transformational change is challenging and the types of barriers that may be encountered. A primary obstacle is that organizational members may not understand new initiatives or may have inaccurate assumptions about them. Two common strategies to addressing this obstacle include sensemaking and organizational learning. Weick (1995) explained sensemaking as steps that 
people take to search for meaning, strive and settle for plausibility, and move forward following those actions. Sensemaking is a cyclical process that begins with the question of "what's going on here?" followed by the question of "what do I do next?" (Weick et al. 2005, p. 412). Initial steps in the sensemaking process occur through actions of "noticing" through which people communicate in order to make sense of circumstances and events that affect them and "bracketing" through which they focus on parts of the overarching problem by reflecting on the external environment. In terms of organizational change and institutional transformation, sensemaking is a process of changing people's mindsets by providing ongoing opportunities for social interaction to introduce new ideas and promote the evolution of the thinking of organizational members (Eckel and Kezar 2003; Weick 1995). These opportunities must be widespread given the decentralized nature of decision making and implementation procedures within postsecondary institutions (Birnbaum 1988; Cohen and March 1974). Ways of creating sensemaking include having ongoing campus conversations, using collaborative leadership, developing cross-departmental teams, sponsoring development opportunities for the faculty and staff, discussing external ideas, preparing public presentations, creating documents and concept papers, and communicating a flexible vision (Kezar 2018).

The second strategy of organizational learning is an approach driven by rational thinking and data use (Kezar 2005). Organizational members create mechanisms for trying new approaches to solving a problem, learn from mistakes, and then further modify practices. Additionally, intra-organizational learning can occur when members learn from other groups that have addressed a similar problem. Organizational learning is typically acknowledged to occur through multiple levels within an organization (Dee and Leišyte 2016). It may begin with an individual sharing an insight that is then transferred to others working within the same group or team. Other members of the group may interpret and modify the information to fit the unique context of the group. In order for the learning to transfer to the organizational level, leadership is needed to identify promising group practices and develop the necessary infrastructure to implement these practices more widely. Feedback from the individual and group levels will continue to refine institutional knowledge. Ways of promoting organizational learning include introducing new ideas, distributing information, providing professional development on data use, creating groups to review and interpret data, promoting critical leadership, and valuing mistakes as learning opportunities (Kezar 2018).

There are two ways to assess whether transformational change has occurred (Kezar 2018). The first type of evidence is a change in the attitudes of organizational members, which may be seen in changes in how groups interact with each other, in the type of language used, and in individuals' perceptions of challenges. The second type of evidence is structural change in the processes or procedures within an organization, such as the widespread use of innovative pedagogies, substantial changes in curricula, or new assessment practices. It is important to consider both types of evidence, as changes in institutional processes alone do not necessarily indicate transformational change.

\section{Hypothesis}

Education of university students will be implemented through a set of the following pedagogical conditions:

- Correction of students' value orientations in the educational process of the university.

- The development of cognitive activity of students.

- The construction of the educational process at the university subject to the requirements of a person-centered approach. 


\section{Methods}

The authors developed the idea of developmental education for university students on the principles of systemicity, activity, humanization, individualization, feedback, integration at the level of interdisciplinary relations, reflective activity, and problematicity. The work is based on the following methods: theoretical - analysis, generalization, systematization, synthesis, modeling; and empirical - conversation, observation, quantitative and qualitative analysis of research results, testing.

Developmental, or remedial, education courses are designed to develop the reading, writing, or math skills of students who are deemed - usually through standardized testsunderprepared for college-level courses. Offering these noncredit courses allows community colleges and less selective four-year colleges to open their doors to students who might otherwise be shut out of higher education. Millions of students - disproportionately students of color, adults, first-generation students and those from low-income backgrounds-enroll in developmental education at two- and four-year colleges. They include students who did not receive an adequate academic foundation in high school and those who have been out of school for years and need a math or English refresher. Although colleges have offered developmental education programs for decades, state policymakers have begun to pay more attention to the growing data that show the weaknesses of developmental education and its impact on college completion, workforce development and equity goals.

The goal of developmental education is to improve students' skills to increase their chances of success in a credit-bearing, college-level program. However, barriers on campus and in federal, state, and institutional policies can slow students' progress toward a degree, which has long-term implications for students and states. This ECS/CAPR brief discusses the importance of and challenges surrounding developmental education and suggests ways in which policymakers can address these challenges.

In July 2018, a change was made to page 4 of this brief to correct the reported findings of a study on severe error rates associated with using standardized assessments to place students into either developmental or college-level courses. The study estimated that 29 percent of students were severely underplaced into developmental English and that 18 percent of students were severely underplaced into developmental math. Counting both these underplacements as well as overplacements into college-level courses that students would likely fail, 33 percent and 24 percent of students were estimated to be severely misplaced in English and math respectively.

\section{Main Part}

Based on works by G.M. Kodzhaspirova, I.A. Zimniaia, I.F. Kharlamov and other researchers, we consider developmental education as one that organically combines acquisition of knowledge, skills, mastering of the experience of creative activity by students and the formation of an emotional and value attitude to the world, to each other, to the studied educational material. The authors of the article are convinced that a holistic approach to education in the learning process involves the unity of all components of the didactic process: goals and objectives, content, methods and forms of organization of training and its results, and pedagogical guidance.

We shall clarify the characteristics of the components of developmental education for university students.

1. Objectives and tasks of developmental education. The holistic construction of developmental education is based on the integration of goals being addressed to the personality of the student and teacher. The convergence of the goals of both the teacher and students depends not only on the achieved level of education and training of students. The dynamics of the unity of upbringing and education, its procedural orientation is adjusted during the implementation of 
educational programs subject to the quality of innovative activity, taking into account subjective factors, in particular, the value attitude of teachers and students to cooperation and joint activities. Setting educational and developmental goals and objectives is a regulated process.

2. The content of developmental education. The main purpose of the content of developmental education is, first of all, to provide a cognitive basis for the development of the student's personality, to master the system of integrated knowledge and skills, and to stimulate students to continuous self-education. Through the content of training, mastering the system of scientific knowledge, university students feel their involvement in social culture, progress, civilization, the development of science and technology. The future of social development is closely connected with what the higher generation teaches the younger generation. The content of education also provides the basis for the formation of a scientific worldview and students' beliefs.

3. Methods of developmental education. The cognitive activity of students, which combines simultaneously occurring cognitive and educational actions, depends on the choice of teaching methods and the associated educational methods. The upbringing function of teaching methods is implemented through updating the students' professional knowledge; through the development of an active, creative, cognitively transforming position of students, through the application of skills. For example, the method of cognitive conversation develops into a method of discussion on ethical topics; a problem situation causes not only cognitive but also moral activity; the oncoming movement of questions from the teacher and students arouses mutual interest in cognition, strengthens research abilities and skills.

4. Forms of organization of developmental education. The educational functions of the forms of organization of educational activity are entirely manifested if the teacher manages to recreate the rules of behavior in the experience of students' practical relationships, to combine the organization of learning with the formation of the experience of humanistic relationships both between students and between students and teachers. For our study, it is important that a wellthought-out educational organization generates students' friendly relations to each other. An elevated, major tone, combined with efficiency and seriousness, make academic work as meaningful and enjoyable for students not only in terms of knowledge acquisition but also in terms of meeting communication needs.

5. Pedagogical management of developmental education. The effectiveness of pedagogical guidance of the developmental learning process depends on the teacher's professional and pedagogical preparedness for the implementation of educational and upbringing tasks, as well as on the style of relationship with students. The relations between the teacher and students, which make up the personal basis of pedagogical interaction, have external and internal sides. The external side is manifested in the ways of presenting requirements, in an individual approach to students, etc.; internal - in mutual understanding and empathy in the process of activity, in the adequacy of actions, estimates, judgments. The driving force of development is the orientation of the teacher on the personal achievements of students and their life values.

6. Results of developmental education. With regard to outcomes, it should be noted that developmental education is closely related to the comprehensive development of the individual. Students learn poly-subject knowledge, master generalized cognitive skills, form a creative attitude towards future professional activities. At the same time, comprehension of scientific knowledge is enriched by moral content. Education takes on a deep humanistic meaning. It develops, becomes more complex, simultaneously promoting the development of a mature, holistic personality of the student. 
Thus, developmental education involves not only the assimilation of university students by knowledge of nature and society, norms of behavior, but also requires a personal attitude to the acquired worldview and moral concepts, the development on their basis of a system of views and beliefs that become principles and motives of behavior. This goal can be achieved through the interaction of all components of developmental education: goals and objectives, content, methods and forms of organization of training and its results, pedagogical guidance.

In our opinion, developmental education at the university will be effective if the following pedagogical conditions are met:

1) Correction of students' value orientations in the educational process of the university.

2) The development of cognitive activity of students.

3) The construction of the educational process at the university subject to the requirements of a person-centered approach.

Let us consider them in more detail:

1) University education provides the student with a set of the most important values he reflects on, gives them evaluative insights, and then masters.

From a pedagogical point of view, values should be considered that is useful for the student's life, which contributes to the development and improvement of his personality. Value can be both a phenomenon of the external world (object, thing, event, act), and a fact of thought (idea, image, scientific concept). It is necessary to clearly imagine that each discipline is, in essence, only a part of the values from the whole set of scientific, artistic, ethical, aesthetic and other values that have already been created for humanity, and proceed from working with a student precisely from this, not allowing hypertrophy of the significance of some and underestimation of other subjects.

2) Cognitive activity as a pedagogical phenomenon is a two-way interconnected process, where cognitive activity, on the one hand, is a form of self-organization and self-actualization of students; on the other hand, it is considered as the result of the teacher's special efforts in organizing the cognitive activity of students. Different students are characterized by different intensities in active learning. The degree of manifestation of the activity of the future professional in the educational process is a dynamic, changing indicator. In this case, we can talk about different levels of cognitive activity of students in educational activities. The authors of the article developed a typology of cognitive activity of university students, which includes such levels as relatively active level; performing and active level, and creative level.

3) However, it should be noted that the implementation of the above conditions is possible only with reliance on the personality of the trainees, on their worldview and subjective experience. Therefore, for the successful organization of developing education at the university, it is necessary to rely on the principles of a personality-oriented approach, since it provides for the creation of conditions for the development of a student in accordance with his natural competency and personal interests. We emphasize that the implementation of person-centered learning requires the development of such a content of education, which includes not only scientific knowledge, but also meta-knowledge, i.e. approaches and methods of scientific knowledge.

The experimental work aimed at checking the selected set of pedagogical conditions was carried out in vivo in the educational process of the university in 2018, 2019, and 2020. The participants were 1-4-year students of various specialties and areas. In total, about 250 people took part in the experiment, including 17 teachers. 


\section{Conclusions}

Summing up the results of the study, we can state as follows. The novelty and theoretical significance of the study consists in clarifying the content of the concept of "developmental educa.-tion of university students" and analyzing its components. The practical significance of the presented study lies in the fact that it systematizes domestic and foreign experience in organizing developmental education of university students, on the basis of which a set of measures has been developed to form and, if necessary, adjust value orientations and levels of students' cognitive activity based on the personal orientation of their learning activities.

All of the above allows us to conclude as follows: education of university students will be developmental within the correction of students' value orientations in the educational process of the university; the development of cognitive activity of students and the construction of the educational process at the university subject to the requirements of a person-centered approach, which confirms the hypothesis put forward by the authors.

\section{References}

Alekseeva, L.F. (2007). Psychological competence of a university teacher. Higher education in Russia, 8. [in Russian].

Ardashkin, I., Martyushev, N., \& Bezborodov, V. (2015). Problem Methodology as One of the Ways of Innovative Organization of Educational Process. Procedia - Social and Behavioral Sciences, 166, 227-231. [in English].

Arokiasamy, A., Hon, Tat. H., \& Abdullah, A. (2013). The effects of rewards system and motivation on job satisfaction: Evidence from the education industry in Malaysia. World Applied Sciences Journal, 24 (12), 1597-1604. [in English].

Bakholskaia, N.A. (2017). The impact of interactive learning on the development of the professional orientation of pedagogical students of higher educational institutions. Humanitarian and pedagogical research. Magnitogorsk: Publishing house of G.I. Nosov Magnitogorsk State Technical University, 1(1), 45-49. [in Russian].

Bakholskaya, N.A., Velikanova, S.S., Baklykova, T.Yu., Mitsan, E.L., Kozhushkova, N.V., Kondrashova, E.N., \& Chernykh, O.P. (2019). The impact of interactive model for university student teaching on their professional competence development. Revista Inclusiones, 6(2), 179-184. [in English].

Bakholskaya, N.A., Velikanova, S.S., Soldatchenko, A.L., Kharitonova, S.V., Kuvshinova, I.A., \& Chernykh, O.P. (2018). Pedagogical reflection and the ways of its development among the students of pedagogical professions. Amazonia Investiga, 7(17), 651-657. [in English].

Bodalev, A. A. (1995). Fundamentals of socio-psychological theory. M., [in Russian].

Bogomolova, E. V. (2009). Methodology and didactics of teacher training for the implementation of person-centered learning. Bulletin of Moscow State University, 2(2), 146-150. [in Russian].

Goncharov, S.Z. (2004). Social competence of an individual: essence, structure, criteria, and significance. Education and Science, 2(26), 3 - 18. [in Russian].

Harold, W. (1965). Bernard. Psychology of Learnind \& Teaching. N.Y., [in English].

Khairullov, Zh.R. (2005). Formation of personality self-actualization in a professional orientation. Integration of education, 3, 156-160. [in Russian].

Poliakova, O.O., \& Lushkina, M.P. (2011). Features of the professional identity of modern students // Bulletin of Moscow State University. 2011. No. 2. P. 69-73. [in Russian].

Sarantsev, G.I. (2016). Harmonization of professional training of bachelors in "Pedagogical education". Integration of education, 2, 211-219. [in Russian].

Serikov, V.V. (1994). Personal approach in education: concepts and technologies: monograph. Volgograd: Peremena, 150 p. [in Russian]. 
Shure, M. B. (1981). Social Competence as a Problemsolving Skill. Social competence. edited by Jeri Dawn Wine \& Marti Diane Smye. - New York, London: The Guilford Press, 158 185. [in English].

Zimnaia, I.A. (2003). Key competencies - a new paradigm of the result of education. Higher education today, 5. [in Russian]. 